\title{
Economic Development of Commercial Crops in Karnataka
}

\author{
Latha $\mathrm{C} \mathrm{M}^{1}$, Ashoka S R ${ }^{2}$, Siddappaji $\mathrm{D}^{3}$, Dr. V Shanmugham ${ }^{4}$ \\ ${ }^{1,2,3}$ Research Scholars Department of Economics and Co-Operation Manasagagothri Mysore \\ ${ }^{4}$ Associate Professor, Mhaharaja College, University of Mysore, Mysore
}

\begin{abstract}
Commercial crops is one of the most essential part of the agriculture sector. In our Indian people basically dependent on agriculture sector. More than 65 percent of people dependent of agriculture sector. Some people engaged in commercial crops activities work. Some people self employed in this crops rural and semi-urban livelihood. In the economic development of World, India and Karnataka level of commercial crops is highly increased in GDP growth rate.
\end{abstract}

\section{Commercial Crops in India}

Indian farming systems are a strategically utilized, to according to the locations where they are most suitable. In the farming systems essentially contributes to the domestic GDP of India are subsistence farming, organic farming and industrial farming. Different type of farming they use; some are based on horticulture, lay farming, agro forestry and also many more. Geographical location of India's, certain parts of experience different climates, agriculture productivity very differently. India is a very most dependent on its monsoon based periodic rainfall. Rainfall is a change in the season to season variations and also significant and the consequence of these are bumper harvests and crop searing. Is one of the main priorities in Indian farming is a irrigation. Ten thousand years background of Indian agriculture. Indian agriculture production in second position in the world.

\section{Objectives:}

1. To Study the Commercial Crops in the World and India

2. To Study the Commercial Crops in the Karnataka

3. To Study the Cash Commercial Crops in Karnataka

\section{Methodology of the Study:}

The study is based on secondary sources of information. The secondary data are collected in various sources, Published article, journals, Newspaper, Karnataka at a Glance, Karnataka Economic Survey and the department of agriculture sector and research article related to it.

World Commercial Crops: World Commercial Crops: United State for use commercial crops during 1996, in the first genetically modified seeds was planted. In the world wide 174 million hectares modified for crops cotton account for almost all commercial production. It is grown mainly in north and south America but also increasing in India, China and South Africa. Adopted a green gene technology in the United State of Americas the farmer. During 2013 genetically modified varieties was exactly 90 percent is a cotton overall, the acreage under genetically modified crop plants increased by one million to 70 million hectares.

Sugarcane is a tropical grass native to Asia. Where it has been growth for over 4000 years. India has been developed by $400 \mathrm{BC}$, method for manufacturing sugar from sugar cane. Sugar introduced to European during the crusades. Sugar was being imported throughout Europe by the $11^{\text {th }}$ century A.D.

Colonial America is a one of the first cash crops in the sugarcane. It was a major sources of income for many plantation it grew plentifully in the southern states. In the 1990s very high labor costs in the united states rapidly conversion to mechanical harvesting.

\section{Commercial Crops in Karnataka:}

Karnataka economy is one of the most essential attribute of Karnataka agriculture. In the topography of Karnataka city's relief, soil and climate immensely supports to the agriculture activities of Karnataka relief, soil conditions and climate jointly contributes in growing crops in the Karnataka city. Agriculture is main considered to be one of the primary occupation for the inhabitants of Karnataka. In Karnataka majority of the people are involved in growing crops especially in the rural areas. Agriculture area of total land 64.6 percent but Karnataka has occupied around 12.31 million hectares. The employment as farmers and agriculture laboures comparing to the 2000-01 to 2010-11 was 71 percent. 
Karnataka is mainly done over three seasons

1. Kharif Crops

2. Rabi Crops

3. Summer Crops

1. Kharif Crops: In the Karnataka kharif crops in comprise millets, paddy, maize(pulses), groundnut, red chilies, cotton, soyabean, sugarcane, rice and turmeric. In the month of kharif crops April to September.

2. Rabi Crops: In the major Rabi crops of Karnataka are wheat, barley, mustard, sesame and peas. It is most popularly known as the harvest in parts of Karnataka. In the month of rabi crops October to December.

Principal Crops: In the stat is very suitable crops for cultivation of different types. In the most important crops grown are:

$>$ Cereals: Rice, Jowar, Bajar, Maize, Wheat, Ragi and Minor Millets.

$>$ Pulses: Tur, Bengalgram, Horsegram, Blackgram, Green gram, cowpea etc.

$>$ Oilseeds: Groundnut, seasmum, sunflower, soyabeen and safflower.

$>$ Commercial Crops: Sugarcane, Cotton and Tobacco.

Karnataka Growers Prefer Cash Crops: Higher prices for cash crops seem to have been encouraged farmers in Karnataka to Cotton, sugarcane and tobacco. Is the main reason poor monsoon coverage and non-availability of fertilizers in a few districts in south interior Karnataka too have a played role in lower sowing of kharif crops in Karnataka. 91.04 lakh hectares in the state is rain-fed areas almost thrice of the 37.89 hectares irrigated areas.

According to agriculture department in the area under kharif is a down by 16.56 percent at 43.97 hectares against 54.14 hectares during the same time last year. 52.70 hectares is a normal coverage. In ironically, the state government had fixed a kharif coverage target of 4.6 hectares.

Main Part of Commercial Crops in Karnataka: We are taking only three important concepts of commercial crops in Karnataka. It's the major role of rural and semi-urban areas in the Karnataka state. Firstly Sugarcane is the most essential part of human livelihood. Every day every person use sugar products. Secondly cotton is use the different way in different season and utilizes the different method. Finally tobacco is the most dangers material. In some details also here:

Sugarcane: Sugarcane is one of the grown primarily in the tropics and subtropics. Sugarcane is grown commercially in Louisiana, taxes and Hawaill and Florida in the United States. During 2011 sugarcane for sugar was 26.7 percent million tones.

Top producing state in Florida, produced more than 13.1 million tons of sugarcane for sugar in 2011. 10.8 million tons of sugarcane produced in Louisiana in the same year. Taxes and Hawaill also produce more than one million tons annually.

According to the 2007 census of agriculture (2009), the number of sugarcane farms dropped from 953 to 692 , while average area harvested grew from 1027 to 1224 acres per farm. World sugar production during 2010-12 is a estimated at 168247 metric tons raw value up to from last year's production. In the world largest producer of sugarcane in a Brazil according to one third of world production. In the second largest producer of sugarcane in the India and fourth world's largest production is China.

Per person use of sugar after peaking during 1972 at 102 ponds in domestic food and beverage industries had declined to a low of 60 ponds per person by 1986. Food manufactures generally the constitute a major portion of the refined sugar deliveries. In the industries, banking and cereal industries are called generally the largest and users of sugar followed by the confectionery makers.

Cotton: Cotton is a very soft and fluffy staple fiber that grows in boll or protective capsule, in the around seeds of cotton plants of the genus gossypium in the family of malvacease. In the fiber is a almost pure cellulose. Under the natural conditions is the cotton bolls will be tend to increase the dispersion of this seeds. Americas, Africa and India in the plant is a shrub native to a tropical and subtropical regions around the world. In the greates diversinty of in will cotton species is a found in Mexio, followed by a Australlia and Africa. Cotton it was a independently domesticated in the old and new worlds.

In the current estimates for world production are 25 million tonners or annually 110 million bales, according to the 2.5 percent of the world's arable land. In the world's highest producer of cotton in China, but most of this is used domestically. So many years have been highest exporter Unites States in the world level.

Tobacco: In the Karnataka tobacco farmers are worried over the proposal to increase tax on a cigarette and the resultant impact on their livelihood. According to B.V Javare Gowda, president, the federation of Karnataka tobacco growers association farmer of tobacco are only concerned on the recommendations of union ministry of health for a steep increasing in tax on cigarette in the budget. In the Karnataka on the flue cured Virginia (FCV) 
tobacco crops in minimum 1 lack small and marginal farmers in Hasana, Mysore and Chamrajnagear district people dependent for their livelihood.

In the apart from growers, nearly, 10 lacks far, worker are only depended on this rain-fed commercial crops. In the Karnataka FCV tobacco grown under the rain-fed conditions and that too in a very low fertile Suisse. In this farmer no alternative work in crop. Increasing the tobacco taxation and the ban on crop comes up, farmer feel this is a king of more information or decisions will Jeopardise the prospects of thousands of small and marginal farmers said Javare Gowda.

Foreign Earning: In the Karnataka tobacco grow in a major foreign exchange earner. Although tobacco crop is a grown on less than 0.3 percent of cultivable land, to tobacco and tobacco products generate excise duty and state taxes to the tune of 28,000 crore annually. In the tobacco exports 6000 crore earn foreign exchange and out of that FCV tobacco alone contributes produce the around 100 million kg of FCV tobacco Andhra Pradesh produces about 270 million $\mathrm{kg}$.

Area Under Commercial Crops (In Hectares)
\begin{tabular}{|c|c|c|c|}
\hline YEARS & COTTON & SUGAR CANE & TOBACOO \\
\hline $2008-09$ & 409024 & 281100 & --------- \\
\hline $2009-10$ & 456802 & 496742 & 118168 \\
\hline $2010-11$ & 545288 & 644610 & 122280 \\
\hline $2011-12$ & 568565 & 646908 & 111218 \\
\hline TOTAL & 1979679 & 2069360 & 351666 \\
\hline
\end{tabular}

Source: Karnataka at a Glance 2012-13

In the area of commercial crops in Karnataka state during 2008-09 to 2011-12. In the different between cotton, sugar cane and tobacoo. On the whole sugarcane is a spread more areas in cultivated in commercial crops 2039360 is a dominated. Followed by cotton is 1979679 and 351666 is tobacoo. In the Karnataka state area spread in commercial crops in sugarcane is more comparing to another two commercial crops.

Production Of Commercial Crops (In Tonnes)
\begin{tabular}{|c|c|c|c|}
\hline YEARS & COTTON & SUGAR CANE & TOBACOO \\
\hline $2008-09$ & 865658 & 23328110 & --------- \\
\hline $2009-10$ & 705079 & 32285023 & 90957 \\
\hline $2010-11$ & 1150117 & 42276713 & 136982 \\
\hline TOTAL & 2720854 & 97889846 & 227939 \\
\hline
\end{tabular}

Source: Karnataka at a Glance 2012-13

In the production of commercial crops in Karnataka state during 2008-09 to 2010-11. In the different between cotton, sugar cane and tobacoo. On the whole sugarcane is a spread more production in cultivated in commercial crops 97889846 is a dominated. Followed by cotton is 2720854 and 227939 tobacoo. In the Karnataka state production spread in commercial crops in sugarcane is more comparing to another two commercial crops.

\section{Conclusion}

A commercial crop is one of the part of agriculture sector in Karnataka state. So many rural and semiurban peoples use in our daily works. Some other people doing self employment in this work. It is also provide employment generation. Most of people utilize the dry land in sugarcane cultivation, cotton and tobacco also. So we are broadly spread this commercial crops in the market structures because developed in our Indian economy.

[1]. 2014 by GMO Compass, March 29-2010

\section{Reference:}

[2]. Business line Bangalore August 15, 2011

[3]. Karnataka at a Glance 2013-14

[4]. Karnataka Economic Survey 2013-14

[5]. www.Commercial Crops in India

[6]. www.Commercial Crops in Karnataka 